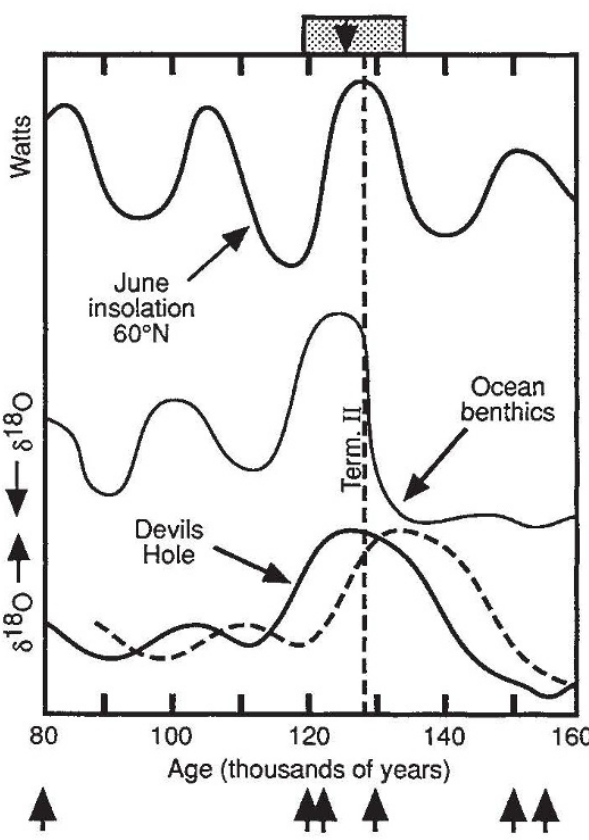

Comparison of the histories of June insolation at $60^{\circ} \mathrm{N}$ and the oxygen isotope records $\left(\delta^{18} \mathrm{O}\right)$ for ocean benthic foraminifera and for Devils Hole calcite for the period surrounding Termination II. Note that for the Devils Hole record (solid line) the termination starts much earlier and is more gradual than it is for the ocean record. Also the duration of the interglacial warm interval is twice as great in the Devils Hole record as in the ocean record. Also keep in mind that Devils Hole ages have not been corrected for the aquifer transit time (hence they are minimum ages). If, for example, this transit time is 15,000 years, the chronology would change as shown by the dashed line. For convenience, the sign of the $\delta^{18} \mathrm{O}$ values for the ocean record has been switched. The small arrows indicate the ${ }^{230} \mathrm{Th}$ age measurements constraining the Devils Hole timescale. The arrow at the top is the accepted ${ }^{230} \mathrm{Th}$ age for corals formed during the last interglacial high sea stand, and the shading shows the range of measured ages.

independent timescale which matches perfectly that based on ${ }^{230} \mathrm{Th}$. Why, after half a million years of uninterrupted growth, should $\mathrm{CaCO}_{3}$ deposition come to a halt? Perhaps it was related to the unroofing at Devils Hole which provides geologists with access to the fault.

In my estimation the new Devils Hole chronology is more firm than any other available isotopic age in this range. Nowhere else has a high degree of concordance between ${ }^{234} \mathrm{U}-{ }^{238} \mathrm{U}$ and ${ }^{230} \mathrm{Th}-{ }^{234} \mathrm{U}$ ages been achieved. No other archive is better preserved. No other record has so many stratigraphically ordered radiometric ages. Winograd and his coinvestigators contend that their Termination II age is superior because the ages for corals from last high sea stand range from 118,000 to 135,000 years.

One puzzling aspect of the Devils Hole record is the long duration of Termination II. In the ocean record this 780 change is quite abrupt (see figure). Radiocarbon measurements for the last termination make a very strong case that these changes are very fast and globally synchronous. The onset of the last termination occurred about 14,000 years ago and it was largely complete by about 9,000 years ago. Radiocarbon dating in the Great Basin, where Devils Hole is located, shows that pronounced drying occurred between 12,000 and 13,000 years ago. Lake Lahontan shrank from its maximum size to a series of small isolated remnants ${ }^{5}$ and Searles Lake dried up altogether ${ }^{6}$. So any explanation requiring a 15,000 year offset in the midpoint of Termination II between Devils Hole and the oceans can be firmly rejected. Perhaps the length of the termination in the Devils Hole record can be attributed to mixing in the aquifer. Water enters the aquifer at several places and flows through a complex web of fractures, so that the isotopic message could be spread out. This might explain not only the slow termination but also the overlong warm period that followed it (see figure). But this cannot be so, as the transit time through the aquifer would have to be 15,000 years or more for dispersion to be important. This traverse time would have to be added to the measured calcite ages - giving an even greater mismatch (see figure).

I remain confused. The geochemist in me says that the Devils Hole chronology is the best we have. And the palaeoclimatologist in me says that correlation between the accepted marine chronology and Milankovitch cycles is just too convincing to be put aside.

The one independent check available is radiometric dating of sediments. Although this direct marine dating method should be far preferred to dating of corals, it relies on there being dependable transport of radiogenic ${ }^{230} \mathrm{Th}$ and ${ }^{231} \mathrm{~Pa}$ from the water column to the sea floor, and so far only the Caribbean has given a trustworthy site. Nonetheless the date so obtained ${ }^{7}$ for Termination II, 128,000 years, fits the accepted marine chronology and we are back where we started. One side will have to give, and maybe - just to be safe - climate modellers should start preparing themselves for a world without Milankovitch.

Wallace S. Broecker is at the LamontDoherty Geological Observatory, Palisades, New York 10964, USA.

\footnotetext{
1. Winograd, I. J. et al. Science 258, 255-260 (1992) 2. Ludwig, K. R. et al. Science 258, 284-287 (1992).

3. Imbrie, J. et al. in Milankovitch and Climate (eds Berger. A. et al.) part 1, 269-305 (Reidel, Boston, 1984). 4. Winograd, l. J. et al. Science 242, 1275-1280 (1988). 5. Benson, L. V. J. Paleolimnol. 5. 115-126 (1991). 6. Smith, G. I. Quat. Res. 22, 1-17 (1984).

6. Smith, G. I. Quat. Res. 22, 1-17 (1984).
7. Broecker, W. S. \& Van Donk, J. Rev. Geophys. Space Phys. 8, 169-197 (1970).
}

\section{Tenacious fibres}

Aтомs attract each other strongly. So why don't solid surfaces stick together on contact? The answer, of course, is that most surfaces are so rough on an atomic scale that they touch at very few points. With more extensive atomic contact, they would stick together firmly.

Nature provides an intriguing example. The gecko, that engaging little tropical lizard, climbs freely up walls and across ceilings, no matter how smooth, rough or porous they may be. It seems to adhere not by glue or suction or mechanical grip but by Van der Waals forces. Its feet have many fine flexible hairs, called setae, which make detailed close contact with any surface. The resulting atomic attractions are strong enough to support the gecko.

Daedalus is now copying this masterpiece of reptilian cunning. His novel 'fractal sticker' is covered with a carefully graded mixture of fibres. The coarsest fibres pack as closely as they can; finer fibres fill the gaps between them; between them are finer fibres still - and so on down to fibres of almost macromolecular dimensions. This subtle structure flows almost like a liquid. Pushed against a surface, the coarse fibres fit themselves into its large-scale contours. The smaller fibres fit round them to fill the smaller irregularities; those smaller still flow into the still tinier gaps, and so on. So the fractal sticker makes intimate contact with any surface, and clings with surprising force. It is best moved by peeling it off from one end, and laying it down in a new position, which is how a gecko moves its feet.

At first Daedalus saw his fractal sticker merely as a novel sole for climbing boots, or a lining for builders' and steeplejacks' gloves. But DREADCO fibre-technologists now plan to make fractal-fibre fabric in bulk, by elaborating the techniques used to make felt, velvet and other furry fabrics. 'Fracfix', as the new product will be called, will cling to any surface without marking or damaging it. It will transform our lives in many ways. Pictures, posters or lettering backed with it will stick firmly on the wall, or even the ceiling, while being easy to remove or reposition. Fracfix-lined belts, straps and webbing will shed their clumsy buckles, and a Fracfixed wig will cling immovably to the shiniest bald pate. Fracfix clothing fabrics will give a wonderful hugging fit. They will bring new security to long stockings and strapless gowns, and will make possible even more daringly unsupported creations. And double-sided Fracfix, holding anything to anything and yet easily and repeatedly removed, will be the handyman's dream. David Jones 